\title{
Truncated Prion Protein and Doppel Are Myelinotoxic in the Absence of Oligodendrocytic $\operatorname{PrP}^{\mathrm{C}}$
}

\author{
Ivan Radovanovic, ${ }^{\star}$ Nathalie Braun, ${ }^{\star}$ Olivier T. Giger, Kirsten Mertz, Gino Miele, Marco Prinz, Beatriz Navarro, \\ and Adriano Aguzzi \\ Institute of Neuropathology, University Hospital of Zurich, CH-8091 Zurich, Switzerland
}

The cellular prion protein $\mathrm{PrP}^{\mathrm{C}}$ confers susceptibility to transmissible spongiform encephalopathies, yet its normal function is unknown. Although $\operatorname{PrP}^{\mathrm{C}}$-deficient mice develop and live normally, expression of amino proximally truncated $\operatorname{PrP}^{\mathrm{C}}(\Delta \operatorname{PrP})$ or of its structural homolog Doppel (Dpl) causes cerebellar degeneration that is prevented by coexpression of full-length $\operatorname{PrP}^{\mathrm{C}}$. We now report that mice expressing $\triangle \mathrm{PrP}$ or Dpl suffer from widespread leukoencephalopathy. Oligodendrocyte-specific expression of full-length $\operatorname{PrP}^{\mathrm{C}}$ under control of the myelin basic protein (MBP) promoter repressed leukoencephalopathy and vastly extended survival but did not prevent cerebellar granule cell (CGC) degeneration. Conversely, neuron-specific $\operatorname{PrP}^{\mathrm{C}}$ expression under control of the neuron-specific enolase (NSE) promoter antagonized CGC degeneration but not leukoencephalopathy. $\operatorname{PrP}^{\mathrm{C}}$ was found in purified myelin and in cultured oligodendrocytes of both wild-type and MBP-PrP transgenic mice but not in NSE-PrP mice. These results identify white-matter damage as an extraneuronal PrP-associated pathology and suggest a previously unrecognized role of $\mathrm{PrP}^{\mathrm{C}}$ in myelin maintenance.

Key words: cerebellum; spinal cord; prion protein; Doppel; leukoencephalopathy; neurodegeneration

\section{Introduction}

The infectious agent causing transmissible spongiform encephalopathies (TSE) was termed prion (Prusiner, 1982). Its only known constituent is $\operatorname{PrP}^{\mathrm{Sc}}$, a TSE-associated isoform of the cellular prion protein $\mathrm{PrP}^{\mathrm{C}}$. Ablation of the Prnp gene, which encodes $\operatorname{PrP}^{\mathrm{C}}$, abrogates prion replication (Büeler et al., 1993) and scrapie pathogenesis (Brandner et al., 1996), but the physiological function of $\operatorname{PrP}^{\mathrm{C}}$ has remained elusive (Aguzzi and Polymenidou, 2004). Prnp ${ }^{\mathrm{o} / \mathrm{o}}$ mice show no obvious developmental defects and enjoy a normal life expectancy (Büeler et al., 1992). Subtle changes in circadian rhythms (Tobler et al., 1996), alterations of hippocampal function (Collinge et al., 1994; Colling et al., 1997; Herms et al., 1999; Mallucci et al., 2002), and behavioral abnormalities have been described. However, some of these phenotypes were not reproduced by others (Lledo et al., 1996), and none were clarified in molecular terms. $\operatorname{PrP}^{\mathrm{C}}$ binds copper

Received Jan. 24, 2005; revised April 4, 2005; accepted April 10, 2005.

This work was supported by grants from the Bundesamt für Bildung und Wissenschaft (European Union), the Swiss National Research Foundation, the United States National Prion Research Program, and the National Centre of Competence in Research on Neural Plasticity and Repair (A.A.). I.R. and N.B. received MD-PhD fellowships from the Swiss Cancer League and the Swiss National Research Foundation. We thank Petra Schwarz for skillful and dedicated help throughout this project and Markus Glatzel for help with NSE-PrP transgenic mice.

*I.R. and N.B. contributed equally to this work.

Correspondence should be addressed to Dr. Adriano Aguzzi, Institute of Neuropathology, University Hospital of Zurich, Schmelzbergstrasse 12, CH-8091 Zurich, Switzerland. E-mail: adriano@pathol.unizh.ch.

I. Radovanovic's present address: Department of Neurosurgery, University Hospital of Geneva, 24 rue Michelidu-Crest, CH-1211 Geneva, Switzerland.

M. Prinz's present address: Institute of Neuropathology, Georg-August-University Göttingen, Robert-KochStrasse 40, D-37075 Göttingen, Germany.

B. Navarro's present address: Centro sui virus e le virosi delle colture Mediterranee, Università degli Studi di Bari, Via Amendola 165/A, 70126 Bari, Italy.

DOI:10.1523/JNEUROSCI.0328-05.2005

Copyright $\odot 2005$ Society for Neuroscience $\quad$ 0270-6474/05/254879-10\$15.00/0
(Brown et al., 1997; Kretzschmar et al., 2000) and may have antiapoptotic properties (Kuwahara et al., 1999; Bounhar et al., 2001; Chiarini et al., 2002; Zanata et al., 2002) but could also sensitize neurons to apoptotic stimuli (Paitel et al., 2003). A possible dismutase activity of $\mathrm{PrP}^{\mathrm{C}}$ was not confirmed in vivo (Waggoner et al., 2000; Hutter et al., 2003). Several factors bind $\operatorname{PrP}^{\mathrm{C}}$, including the laminin receptor precursor protein (Rieger et al., 1997), heparan sulfate (Caughey et al., 1994), neural cell adhesion molecule (NCAM) (Schmitt-Ulms et al., 2001), and bcl-2 (Kurschner et al., 1995). However, none of these interactions were shown to be functionally significant. Hence, no unified view of $\operatorname{PrP}^{\mathrm{C}}$ function has emerged from the above observations.

Transgenic expression of amino proximally truncated $\operatorname{PrP}^{\mathrm{C}}$ mutants causes early-onset ataxia associated with progressive cerebellar granule cell (CGC) degeneration and death at 3-4 months of age, also referred to as Shmerling's syndrome (Shmerling et al., 1998). Only truncated versions of $\operatorname{PrP}^{\mathrm{C}}$ encompassing half (amino acids $\Delta 34-121$ ) or all (amino acids $\Delta 34-134$ ) of the highly conserved hydrophobic transmembrane domain 1 (TM1) region (amino acids 113-134) (collectively termed $\Delta \mathrm{PrP}$ ) induce disease. A similar neurodegenerative phenotype affecting cerebellar Purkinje cells was observed in compound heterozygous Prnp ${ }^{\text {o/ZHII }}$ mice and in homozygous Prnp ${ }^{\text {ZHII/ZHII }}$ mice (Rossi et al., 2001), whose targeted Prnp ${ }^{\text {ZHII }}$ allele (termed “ZHII" because it was the second targeting event of Prnp executed in Zurich) leads to overexpression of the $\operatorname{PrP}^{\mathrm{C}}$ homolog Doppel (Dpl) (Weissmann and Aguzzi, 1999). This phenotype is only observed in $\operatorname{Prn} \mathrm{p}^{\mathrm{o} / \mathrm{o}}$ mice that overexpress $\triangle \mathrm{PrP}$ or $\mathrm{Dpl}$ and is fully reverted by substoichiometric coexpression of full-length $\operatorname{PrP}^{\mathrm{C}}$, as either the original endogenous Prnp locus or a transgene under transcriptional control of a "half-genomic" miniversion of Prnp (Fischer et al., 1996). It follows that $\triangle \mathrm{PrP}$ and $\mathrm{Dpl}$ interfere with a physiological function of $\operatorname{PrP}^{\mathrm{C}}$. 
Here we show that, in addition to CGC degeneration, mice expressing $\Delta \mathrm{PrP}$ or $\mathrm{Dpl}$ in their brain suffer from widespread cerebellar leukoencephalopathy. Oligodendrocyte-specific expression of $\mathrm{PrP}^{\mathrm{C}}$ repressed this pathology and restored long-term survival but did not rescue CGC death. Conversely, neuronspecific expression of $\mathrm{PrP}^{\mathrm{C}}$ delayed disease onset and antagonized, to some extent, CGC degeneration but did not prevent white-matter degeneration. Therefore, white-matter disease and CGC degeneration are independent of each other. Surprisingly, white-matter disease appears to represent a major survivallimiting pathology induced by a toxic PrP mutant.

\section{Materials and Methods}

Generation of myelin basic protein-PrP and neuron-specific enolase-PrP transgenic mice. Mice hemizygously transgenic for the F35( $\operatorname{PrP} \Delta 32-$ $134)^{+/-}$allele (Shmerling et al., 1998) and hemizygous for the ablated endogenous Prnp locus (Prnp ${ }^{+/ Z H I}$ ) (Büeler et al., 1992) are referred to

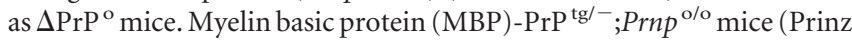
et al., 2004) were crossed to $\Delta \operatorname{PrP}^{\circ}$ or to compound Prnp ${ }^{\mathrm{ZHI} / \mathrm{ZHII}-\mathrm{Loxl}}$ mice (Rossi et al., 2001). The wild-type and neo-targeted Prnp loci were detected by PCR analysis of tail DNA as described previously (Büeler et al., 1992), the F35( $\operatorname{PrP} \Delta 32-134)$ transgene was detected as described previously (Shmerling et al., 1998), and the ZHII-lox1 locus was also detected as described previously (Rossi et al., 2001). To detect the MBP-PrP transgene, the following primers were used: $5^{\prime}$-ggc aac gtg ctg gtt att gtg c-3' and $5^{\prime}$-tcc cca gca tgt agc cac caa gg- $3^{\prime}$ (annealing at $58^{\circ} \mathrm{C}$ ). For the generation of neuron-specific enolase (NSE)-PrP ${ }^{+/-} ; \mathrm{F} 35(\operatorname{PrP} \Delta 32-134)^{+/-}$mice, NSE$\mathrm{PrP}^{+/+} ;$Prnp $^{o / o}$ mice were crossed with F35(PrP $\left.\Delta 32-134\right)^{+/-} ;$Prnp $^{+/ o}$ animals. Primers used were as follows: Prnpint2, 5' -ATA CTG GGC ACT GAT ACC TTG TTC CTCA T; P10rev, 5'-GCT GGG CTT GTT CCA CTG ATT ATG GGT AC. These primers amplify selectively the wild-type Prnp allele but not the NSE-PrP transgene and were used to identify animals negative for wild-type Prnp. Standard PCR for Prnp (Büeler et al., 1992) detected both the NSE-PrP and the wild-type Prnp allele and was used to confirm the inheritance of the NSE-PrP in animals lacking wild-type Prnp. Onset of disease was declared when animals exhibited unambiguous tremor or unsteady gait that was blindly recognizable from healthy littermates in the same cage by two different observers. Animals were considered to be at a terminal disease stage when they developed hindlimb paralysis and were unable to reposition for $10 \mathrm{~s}$ after having been turned back-down.

Histopathology. Organs were fixed in 4\% paraformaldehyde (PFA) in PBS, $\mathrm{pH}$ 7.5, paraffin embedded, and cut into $2 \mu \mathrm{m}$ sections. Brain sections were stained with hematoxylin-eosin, Luxol-Nissl (myelin and neurons), and commercial antibodies to GFAP (Dako, Carpinteria, CA), microtubule-associated protein-2 (MAP-2) (Chemicon, Temecula, CA), CNPase (Roche, Basel, Switzerland), or phosphorylated neurofilament protein (Sigma, St. Louis, MO). For major histocompatibility complex class II (MHC-II) and CD1 1 b stains, tissues were snap frozen in OCT, cut on a vibratome, and stained with antibodies to CD11b (PharMingen, San Diego, CA) or MHC-II (Serotec, Oxford, UK). Antibody stainings were visualized using the peroxidase-anti-peroxidase method or a fluorescent secondary antibody. Apoptosis was assessed using the in situ cell death kit (Roche) according to the instructions of the manufacturer.

Semithin sections and electron microscopy. Mice were perfused with ice-cold $4 \% \mathrm{PFA} / 3 \%$ glutaraldehyde. Brains and spinal cord were removed, immersed in the same solutions, and kept at $4^{\circ} \mathrm{C}$ until processing. Tissues were embedded in Epon, and semithin sections were stained with toluidine blue or used for electron microscopy.

Myelin preparation. Myelin was purified from mouse brains as described previously (Norton and Poduslo, 1973). Brain homogenates (5\% $\mathrm{w} / \mathrm{v}$ ) were prepared in $0.32 \mathrm{~m}$ sucrose. An aliquot of the homogenate was stored at $-80^{\circ} \mathrm{C}$. The rest was layered over $0.85 \mathrm{M}$ sucrose and centrifuged at $75,000 \times g$ for $30 \mathrm{~min}$. Crude myelin was collected from the interface, resuspended in water, and centrifuged at $75,000 \times g$ for $15 \mathrm{~min}$. The resultant pellet was osmotically shocked in deionized water to remove contaminants from within myelin vesicles and centrifuged twice at $12,000 \times g$ for $15 \mathrm{~min}$. The pellets were resuspended in $0.32 \mathrm{M}$ sucrose, layered over $0.85 \mathrm{~m}$ sucrose, and centrifuged at 75,000 $\times \mathrm{g}$ for $30 \mathrm{~min}$. Myelin was again collected from the interface, resuspended in deionized water, and pelleted at $75,000 \times g$ for 15 min to remove residual sucrose. Finally, myelin was resuspended in water and stored at $-80^{\circ} \mathrm{C}$. Equal amounts of myelin preparation were then processed for immunoblotting using an anti-PrP antibody [ICSM-18 (White et al., 2003) or POM-1 (M. Polymenidou and A. Aquzzi, unpublished observation)], an anti-NCAM antibody (Research Diagnostics, Flanders, NJ), or an anti-GFAP antibody (Dako, Glostrup, Denmark).

Oligodendrocyte cultures. Mixed glial cell cultures containing oligodendrocytes and astrocytes were produced from 1-d-old neonatal mice as described previously (McCarthy and de Vellis, 1980; Trotter and Schachner, 1989). Cultures were prepared with high-glucose DMEM supplemented with $10 \%$ fetal bovine serum and replenished on day 4 and every 3-4 d thereafter for $10 \mathrm{~d}$ with DMEM plus $10 \%$ heat-inactivated horse serum. Oligodendrocytes were purified from mixed glial cultures by differential detachment and negative selection of microglia by adherence to hydrophobic plastic. Purified oligodendrocytes were then plated onto glass or plastic culture chambers coated, respectively, with 100 or 10 $\mu \mathrm{g} / \mathrm{ml}$ poly-L-lysine. Oligodendrocyte precursors were expanded with PDGF- and FGF-supplemented SATO medium $[400 \mathrm{ng} / \mathrm{ml}$ T3, $400 \mathrm{ng} / \mathrm{ml} \mathrm{T4}, 2 \mathrm{mmol} / \mathrm{L}$ glutamine, $50 \mathrm{U} / \mathrm{ml}$ penicillin, $50 \mathrm{~g} / \mathrm{ml}$ streptomycin, and $5 \mathrm{ml}$ of $\mathrm{N} 2$ supplement (Invitrogen, Paisley, UK)] for $2 \mathrm{~d}$ and subsequently differentiated with $1 \%$ horse serum-supplemented SATO medium. After $3 \mathrm{~d}$ of differentiation, cells were washed with PBS and homogenized in PBS containing 0.5\% NP-40, 0.5\% sodium deoxycholate, and protease inhibitors (Roche). Homogenate was then incubated on ice for $30 \mathrm{~min}$ and centrifuged at 10,000 rpm for $15 \mathrm{~min}$ at $4^{\circ} \mathrm{C}$. Equal amounts of lysate were then processed for immunoblotting with a mouse monoclonal antibody to PrP (ICSM-18) (White et al., 2003) and with a mouse monoclonal anti-actin antibody (Chemicon).

Flotation assays. Flotation of detergent-insoluble complexes was performed as described previously (Naslavsky et al., 1997). Appropriate brain homogenates were extracted for $1 \mathrm{~h}$ on ice in cold lysis buffer $(150$ mм NaCl, 25 mm Tris-HCl, pH 7.5, 5 mm EDTA, and 1\% Triton X-100; total protein, $30 \mu \mathrm{g}$ in $100 \mu \mathrm{l})$. Extracts were mixed with two volumes $(200 \mu \mathrm{l})$ of $60 \%$ Optiprep (Axis Shield, Oslo, Norway) to reach a final concentration of $40 \%$. All lysates were loaded at the bottom of Beckman Instruments (Fullerton, CA) ultracentrifuge tubes. A 5-30\% Optiprep step gradient in TNE (in mM: $150 \mathrm{NaCl}, 25$ Tris-HCL, pH 7.5, and 5 EDTA) was then overlaid onto the lysate (1300 $\mu \mathrm{l}$ of $30 \%$ Optiprep and $300 \mu \mathrm{l}$ of $5 \%$ Optiprep). Tubes were centrifuged for $12 \mathrm{~h}$ at $4^{\circ} \mathrm{C}$ in a TLS55 Beckman Instruments rotor at 100,000 $\times$ g. Fractions $(200 \mu \mathrm{l})$ were collected from the top of the tube and processed for immunoblotting and visualization with an anti-PrP antibody [ICSM-18 (White et al., 2003) or POM-1 (Polymenidou and Aquzzi, unpublished observation); both detect the PrP core and display identical patterns] and an antiflotillin 1 antibody (BD Transduction Laboratories, Lexington, KY).

Western blot analysis of myelin proteins. Brains and spinal cords were removed and homogenized in lysis buffer containing $1 \%$ Nonidet P-40, $0.5 \%$ sodium deoxycholate, $0.1 \%$ SDS, $1 \mathrm{~mm}$ sodium orthovanadate (Fluka, Basel, Switzerland), and protease inhibitors (Roche) in PBS. Homogenates were incubated on ice for $30 \mathrm{~min}$ and centrifuged at 10,000 $\mathrm{rpm}$ for $10 \mathrm{~min}$ at $4^{\circ} \mathrm{C}$. Equal amounts of lysate $(10 \mu \mathrm{g}$ of protein for spinal cord and $20 \mu \mathrm{g}$ of protein for brain homogenate) were separated by electrophoresis on $12 \%$ SDS-PAGE gels and transferred to nitrocellulose membranes. The membranes were probed with antibodies to MBP (Chemicon), myelin-associated glycoprotein (MAG) (Chemicon), proteolipid protein (PLP) (Chemicon), 2', 3'-cyclic nucleotide 3'phosphodiesterase (CNP) (Abcam, Cambridge, UK), and actin (Chemicon). The amount of MBP, MAG, and actin was quantified using a VersaDoc model 4000 Imaging System (Bio-Rad, Zurich, Switzerland).

Northern blots. Brains were collected and immediately snap frozen in liquid nitrogen before storage at $-80^{\circ} \mathrm{C}$ until required. Total RNA was isolated using Trizol (Invitrogen, Basel, Switzerland) with a T18 Basic Disperser (Ika Works, Staufen, Germany). Northern blot hybridization experiments were performed according to standard procedures (Sambrook and Russell, 2001) using $15 \mu \mathrm{g}$ of total RNA. Random primed $\left[\alpha-{ }^{32} \mathrm{P}\right]$ deoxyCTP probes were prepared from $20 \mathrm{ng}$ of gel-purified DNA 

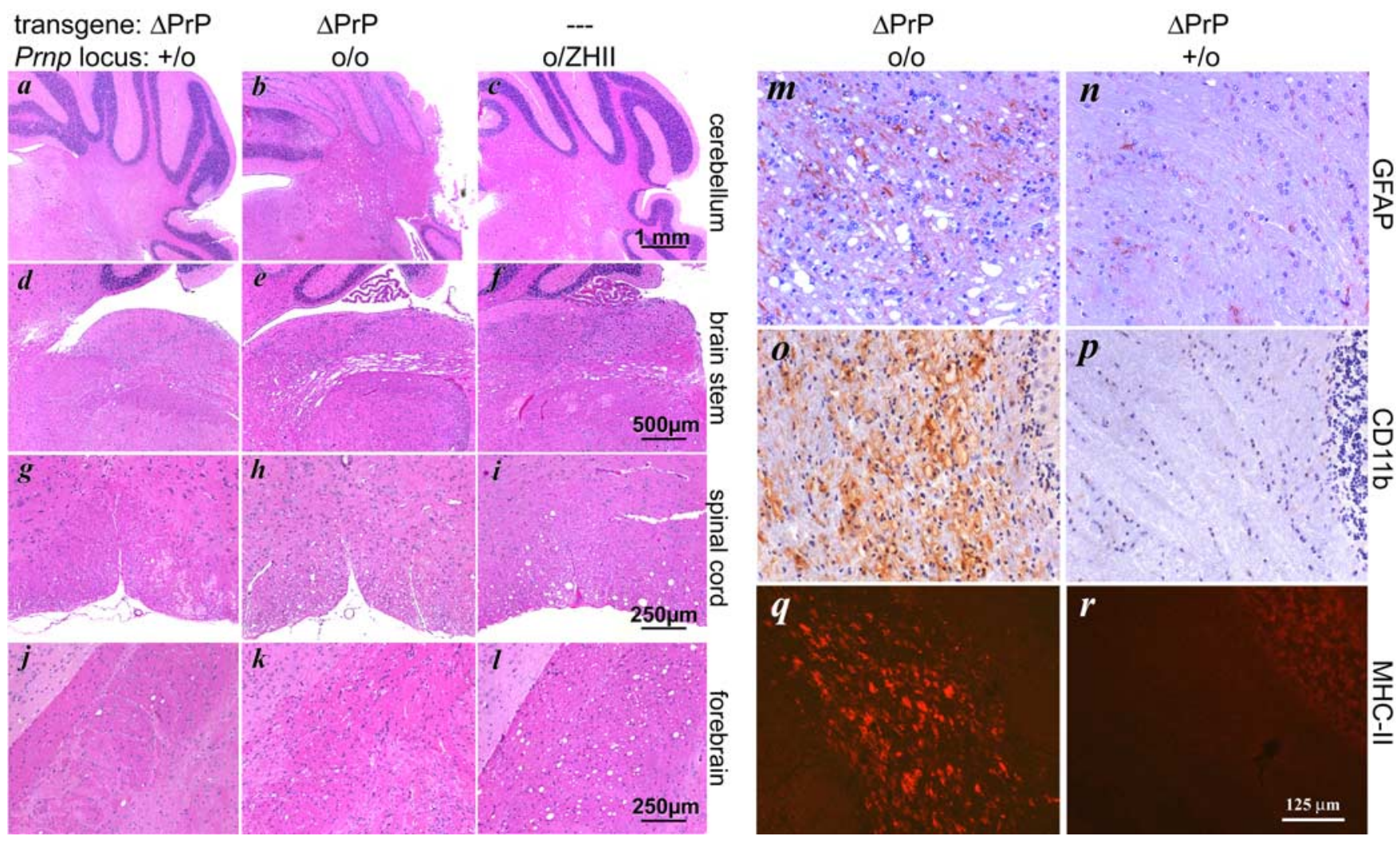

Figure 1. White-matter pathology in $\Delta \operatorname{PrP}^{0}$ and $P r n p^{0 / Z H I I I}$ mice. $\boldsymbol{a}-\boldsymbol{I}$, Vacuolar degeneration in the cerebellar peduncles $(\boldsymbol{a}-\boldsymbol{c})$, the intrapontine segments of the trigeminal nerve $(\boldsymbol{d}-\boldsymbol{f})$, and the anterior spinal cord columns $(\boldsymbol{g}-\boldsymbol{i})$ of 4-month-old $\Delta \mathrm{PrP}^{0}$ and 18-month-old Prnp ${ }^{0 / Z H I I I}$ mice. Prnp ${ }^{0 / Z H I I I}$ mice showed additional vacuolation of forebrain white-matter tracts, including the pyramidal tracts $(/)$ and the corpus callosum (data not shown). $\Delta \operatorname{PrP}$ transgenic mice hemizygously expressing wild-type $\operatorname{Prnp}\left(\Delta \operatorname{PrP}^{+}\right)$did not develop pathological changes $(\boldsymbol{a}, \boldsymbol{d}, \boldsymbol{g}, \boldsymbol{j}) . \boldsymbol{m}-\boldsymbol{r}$, Astrogliosis and microglia activation in the white matter of $\Delta \mathrm{PrP}^{\circ}$ but not of $\Delta \mathrm{PrP}^{+}$mice. Astrocytes were visualized with antibodies to $\mathrm{GFAP}(\boldsymbol{m}, \boldsymbol{n})$, whereas activated microglia and macrophages were stained with antibodies to CD11b $(\boldsymbol{o}, \boldsymbol{p})$ and $\operatorname{MHC}-I I(\boldsymbol{q}, \boldsymbol{r})$.

homologous to target transcripts using a Rediprime II random priming kit (Amersham Biosciences, Otelfingen, Switzerland) and purified with Nick Sephadex G50 columns (Amersham Biosciences). Prehybridization and hybridization were performed overnight at $42^{\circ} \mathrm{C}$ using Ultrahyb (Ambion, Austin, TX), containing $1 \times 10^{6} \mathrm{cpm} / \mathrm{ml}$ radiolabeled probe, $100 \mu \mathrm{g} / \mathrm{ml}$ denatured herring sperm DNA (Catalysis), and $20 \mu \mathrm{g} / \mathrm{ml}$ denatured yeast tRNA (Fluka). Posthybridization washes were performed according to Ultrahyb instructions. Hybridization signals were quantified using Fujifilm (Tokyo, Japan) imaging plate technology (BAS1800II) and normalized for variations in RNA loading by subsequent probing with an excess of $18 \mathrm{~S}$ ribosomal RNA cDNA probe (Miele et al., 1998).

\section{Results}

Myelinopathy and axonal degeneration in $\triangle \operatorname{PrP}^{o}$ mice

Hemizygous hg- $\operatorname{PrP} \Delta(32-134)^{\mathrm{tg} /-}$ transgenic mice, which express amino proximally truncated $\operatorname{PrP}^{\mathrm{C}}$ under transcriptional control of a half-genomic Prnp minigene (Fischer et al., 1996) (henceforth termed $\Delta \mathrm{PrP}^{+}$mice) were bred to $\operatorname{Prnp}^{\mathrm{o} / \mathrm{o}}$ mice. The resulting mice (termed $\left.\Delta \operatorname{PrP}^{\circ}\right)$, hemizygous for the hg- $\operatorname{PrP} \Delta(32-$ 134) transgene and devoid of both endogenous Prnp alleles, developed CGC degeneration as described previously (Shmerling et al., 1998) (Fig. 1a,b). In addition, histological analysis of terminally sick $\Delta \mathrm{PrP}^{\circ}$ brains revealed additional coarse vacuolar degeneration of the intrapontine part of cranial nerves (Fig. 1d,e). Also, substantial areas of white matter in the cerebellum, the brainstem, as well as the anterior and lateral spinal cord columns exhibited large vacuoles, astrogliosis, and activated microglia/ macrophages (Fig. 1m-r).

We also bred heterozygous and homozygous hg- $\operatorname{PrP} \Delta(32-$ $121)^{\operatorname{tg}}$ transgenic mice, which express a Prnp version with a smaller deletion than the $\operatorname{hg}-\operatorname{PrP} \Delta(32-134)$ transgene, to the $\operatorname{Prnp}^{\mathrm{o} / \mathrm{o}}$ genetic background. We found that both the hg$\operatorname{PrP} \Delta(32-121)$ and hg- $\operatorname{PrP} \Delta(32-134)$ transgenes induced analogous white-matter lesions in $\operatorname{Prnp}^{\mathrm{o} / \mathrm{o}}$ mice (data not shown). Therefore, in all experiments described below, we used $\Delta P r P^{o}$ mice as a general paradigm for the toxicity of amino proximally truncated $\mathrm{PrP}^{\mathrm{C}}$.

Myelinated fibers in spinal cord and cerebellar white matter displayed severe axonal loss associated with large vacuoles and degeneration of myelin sheaths into condensed spheroids (Fig. $2 a-f)$. Semithin sections and electron microscopy did not evidence any abnormality in myelin thickness, spacing, and periodicity in $\Delta \operatorname{PrP}^{\circ}$ and $\Delta \mathrm{PrP}^{+}$mice (Fig. $2 i$ ), but many individual sheaths displayed vacuoles, especially around large axons. Axonal pathology was evident in the latter areas. Some axons were swollen and featured accumulation of mitochondria and dense bodies (Fig. 2j,k). Other axons suffered from compromised adhesion to their myelin sheaths, evident as periaxonal splitting over broad portions of the axolemma and detachment from the myelin wrap (Fig. 2l,m). Many axons had completely degenerated, leaving behind empty myelin rings or collapsed and condensed residual myelin ghosts (Fig. 2n,o).

Axon-myelin pathology may result from developmental myelination failure or, alternatively, from degeneration of myelinated axons after completion of normal development. This question was addressed by studying semithin spinal cord and cerebellar white-matter sections from postnatal day 25 mice, 

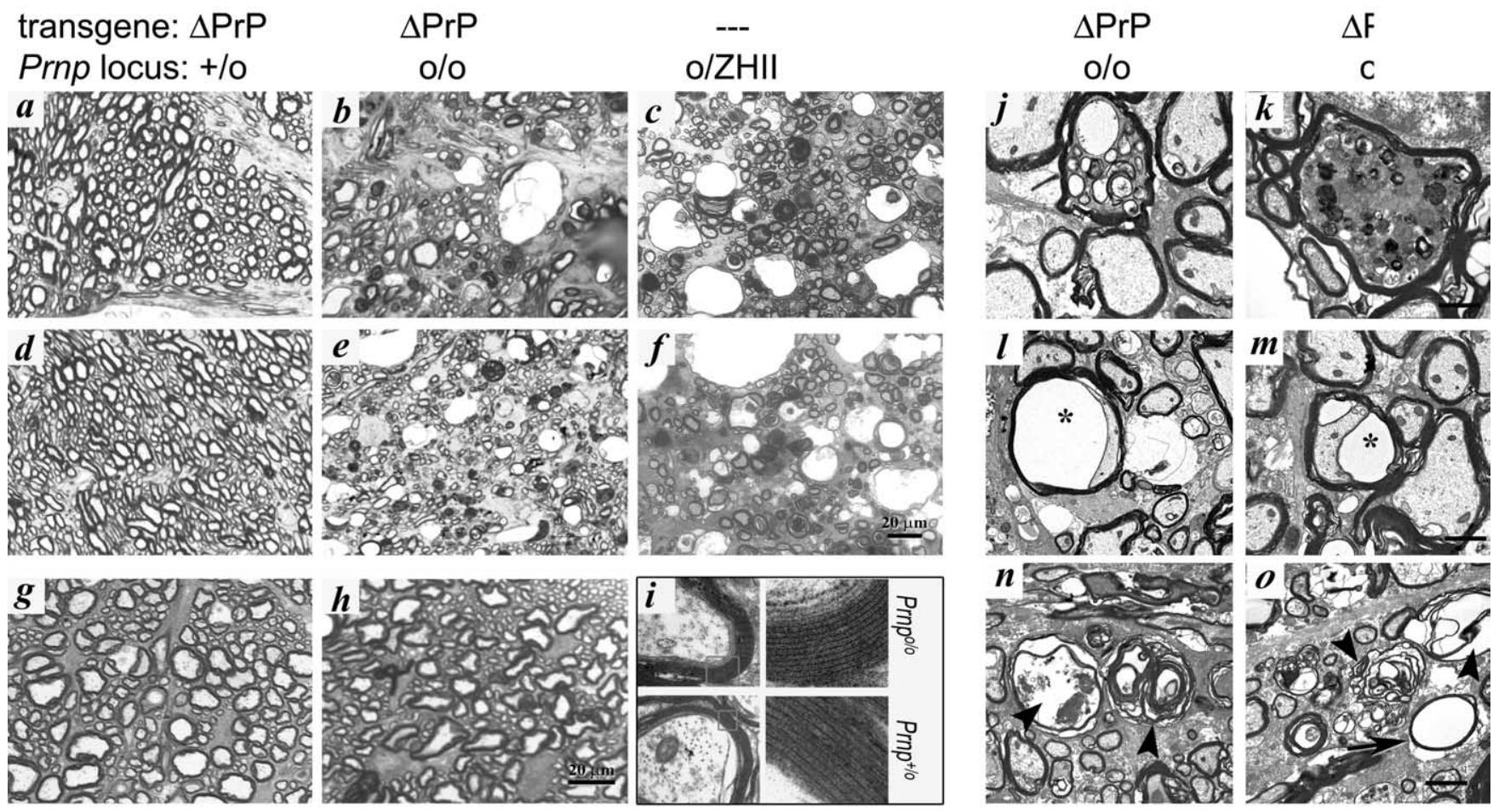

Figure 2. Axon and myelin degeneration in $\Delta \operatorname{PrP}^{0}$ and $\operatorname{Prnp} p^{\text {o/ZHIII }}$ mice. $\boldsymbol{a}-\boldsymbol{f}$, Toluidine blue-stained semithin sections of spinal cord ( $\boldsymbol{a}-\boldsymbol{c}$ ) and cerebellar white matter $(\boldsymbol{d}-\boldsymbol{f})$ of clinically healthy $\Delta \operatorname{PrP}^{+}(\boldsymbol{a}, \boldsymbol{d})$ and terminally sick $\Delta \operatorname{PrP}^{\circ}(\boldsymbol{b}, \boldsymbol{e})$ and $\operatorname{Prnp^{0/ZHII}}(\boldsymbol{c}, \boldsymbol{f})$ mice. Axonal loss, vacuolation, and axon-myelin degeneration were visible in $\Delta \operatorname{PrP}^{0}$ and $\operatorname{Prnp}{ }^{0 / Z H I I}$ mice but absent from $\Delta \operatorname{PrP}^{+}$ mice. No axon-myelin degeneration was seen in 25 -d-old $\Delta \operatorname{PrP}^{\circ}$ mice $(\boldsymbol{g}, \boldsymbol{h})$, suggesting that it is a late-onset pathology. Scale bar, $20 \mu \mathrm{m}$. Electron microscopic analysis showed regular spacing and periodicity of $\operatorname{PrP}^{\circ}$ myelin $(i)$, whereas $\Delta \mathrm{PrP}^{\circ}$ white matter presented with axonal swellings and spheroids with accumulation of membranous organelles, mitochondria, and undefined dense bodies $(\boldsymbol{j}, \boldsymbol{k})$, as well as defects in axon-glial adhesion $(\boldsymbol{I}, \boldsymbol{m})$ with axon-myelin detachment and optically empty myelin cavities (asterisk). $\boldsymbol{n}, \boldsymbol{o}$, More advanced stages of degeneration included axonal degeneration with empty myelin rings (arrow) and collapse of myelin in condensed multilamellar spheroid structures (arrowheads). Scale bar, $5 \mu \mathrm{m}$.

shortly after completion of the myelination process. We found no vacuolation, hypomyelination, or axonal loss at this early stage (Fig. $2 g, h$ ), suggesting that pathological changes occur after myelination and are of degenerative rather than developmental origin.

Although florid apoptosis was only found in CGCs, as described previously (Shmerling et al., 1998), abnormal accumulations of perikaryal phosphorylated neurofilament proteins were visible in degenerating CGCs, as well as in brainstem and spinal cord neurons (Fig. 3), implying that neurons other than CGCs may also be affected by $\Delta \mathrm{PrP}$ toxicity. Additionally, this suggests that axonal damage and pathologic cytoplasmic accumulation of phosphorylated neurofilament are a primary consequence of $\Delta$ PrP expression rather than secondary to neuronal cell death. We considered whether axon-myelin degeneration might result from oligodendroglial damage. However, no apoptosis was found in the white matter of diseased animals (Fig. 3), suggesting that oligodendrocyte survival was not generally impaired by $\Delta$ PrP. Therefore, general oligodendroglial cytotoxicity is unlikely to account for white-matter pathology.

\section{White-matter pathology in $\operatorname{Prnp}^{o / o}$ mice overexpressing Dpl} The prion protein homolog Dpl bears structural resemblance to $\Delta \operatorname{PrP}$ (Luhrs et al., 2003) and is encoded by the Prnd gene, which is situated $16 \mathrm{~kb} \mathrm{3'}$ of Prnp. In homozygous Prnp ${ }^{\text {ZHII/ZHII }}$ and in compound heterozygous Prnp ${ }^{\mathrm{ZHII} / \mathrm{o}}$ mice, loxP-mediated deletion of the entire third Prnp exon induces atypical intergenic splicing patterns that place Dpl under transcriptional control of the Prnp promoter, thereby leading to Dpl overexpression in brain (Weissmann and Aguzzi, 1999; Rossi et al., 2001). Overex- pression of Prnd leads to cerebellar degeneration, possibly by similar mechanisms as $\Delta \operatorname{PrP}$ (Moore et al., 1999; Genoud et al., 2004). We therefore analyzed the white matter of 18 -month-old Prnp ${ }^{\mathrm{ZHI} / \mathrm{o}}$ mice with advanced clinical disease. We found whitematter vacuolation similar to that of $\Delta \operatorname{PrP}^{\circ}$ mice (Fig. $1 c, f, i$ ). Unexpectedly, white-matter disease was not restricted to cerebellum, brainstem, and spinal cord, but extended into the forebrain white matter, the pyramidal projections, and the corpus callosum (Fig. $1 j-l$ ).

\section{Oligodendroglial $\operatorname{PrP}^{\mathrm{C}}$ represses leukoencephalopathy but not granule cell degeneration}

Axons and their myelin sheaths are functionally dependent on each other: degeneration in one compartment may result in secondary damage to the other compartment. Alternatively, damage may result from parallel primary toxicity to both compartments. If myelin-producing oligodendrocytes were a primary target of mutant $\mathrm{PrP}^{\mathrm{C}}$ and $\mathrm{Dpl}$, selective oligodendrocytic expression of $\operatorname{PrP}^{\mathrm{C}}$ should repress white-matter pathology. We therefore crossed $\Delta \mathrm{PrP}^{\circ}$ mice to $\operatorname{tg} 640$ mice, which express full-length $\operatorname{PrP}^{\mathrm{C}}$ under transcriptional control of a myelin basic protein promoter fragment (Fig. 4a) (Prinz et al., 2004).

Hemizygous expression of the MBP-PrP transgene significantly delayed the onset of tremor and ataxia (mean time of onset, $74 \pm 3$ vs $43 \pm 2 \mathrm{~d}$; $p<0.0001$ ) (Table 1, Fig. $4 a, c$ ) and reduced the typical wasting of $\Delta \mathrm{PrP}^{\circ}$ mice (body weight at 8 weeks of age, $22.2 \pm 0.39$ vs $14.8+0.29 \mathrm{~g} ; p<0.0001) . \Delta \operatorname{PrP}^{\circ}$ mice reached terminal disease at 3-4 months of age, with severe wasting and hindlimb paralysis. In contrast, $\triangle \operatorname{PrP}^{\circ} \mathrm{MBP}-\mathrm{PrP}^{\mathrm{tg} /}$ littermates were ataxic, but weight loss was not as severe as in 


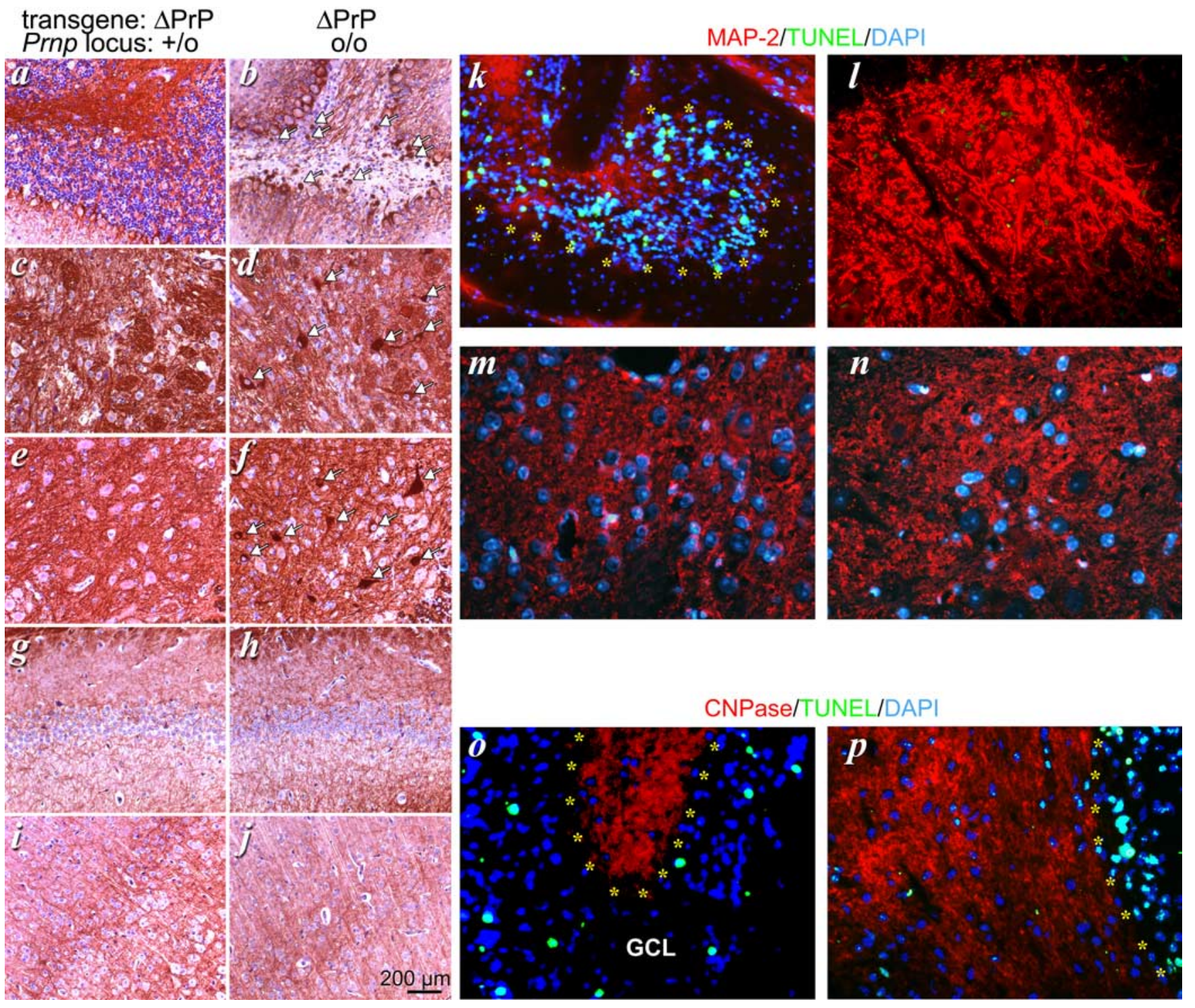

Figure 3. Neuronal damage but no oligodendroglial or extracerebellar apoptosis. $\boldsymbol{a}-\boldsymbol{j}$, Immunostains for phosphorylated neurofilaments. Pathological neurofilament deposits (arrows) were evident in $\triangle \operatorname{PrP}^{\circ} \mathrm{CGC}(\boldsymbol{b})$, as well as in spinal $(\boldsymbol{d})$ and brainstem $(\boldsymbol{f})$ neurons but not in hippocampal and cortical neurons $(\boldsymbol{h}, \boldsymbol{j})$, suggestive of selective neuronal pathology and possible axonal impairment. No hyperphosphorylated neurofilaments were found in $\Delta \operatorname{PrP}^{0} \times \operatorname{Prnp}{ }^{+/ 0}$ mice $(\boldsymbol{a}, \boldsymbol{c}, \boldsymbol{e}, \boldsymbol{g}, \boldsymbol{i})$. In the CGC layer (asterisks), many MAP-2 ${ }^{+}$granule cells were terminal deoxynucleotidyl transferase-mediated biotinylated UTP nick end labeling (TUNEL) positive (green, $\boldsymbol{k}$ ), but no MAP-2 ${ }^{+}$apoptotic cells were found in spinal cord $(\boldsymbol{I})$, brainstem $(\boldsymbol{m})$, cortex ( $\boldsymbol{n}$ ), or hippocampus (data not shown). No TUNEL ${ }^{+}$cells were found in the white matter, which instead contained CNPase ${ }^{+}$(red) oligodendrocytes $(\boldsymbol{o}, \boldsymbol{p})$. TUNEL ${ }^{+} / \mathrm{CNPase}^{-} \mathrm{CGCS}^{-}$served as internal controls. Asterisks delineate CGC layer and white matter (red). Nuclei are 4',6-diamidino-2-phenylindole positive (DAPI, blue). GCL, Granule cell layer.

$\Delta \mathrm{PrP}^{\circ}$ mice. The weight of 1-year-old $\Delta \mathrm{PrP}^{\circ} \mathrm{MBP}-\mathrm{PrP} \mathrm{P}^{\mathrm{tg} /-}$ was still 17-19 g. Remarkably, these mice achieved long-term survival ( $>400 \mathrm{~d})$, with stable or minimally progressing disease, whereas the mean survival time of $\Delta \operatorname{PrP}^{\circ}$ littermates was $99 \pm 5.3 \mathrm{~d}$ (Fig. $4 a, c)$. Histological analysis showed repression, but not complete rescue, of axon-myelin degeneration and white-matter vacuolation (Fig. $4 g-j$ ). Instead, no rescue of CGC was observed (Fig. $4 e, f)$, confirming that white-matter disease is unrelated to CGC degeneration. These results strengthen the conjecture that myelin is a direct target of $\Delta \operatorname{PrP}$ toxicity.

Compound heterozygous Prnp ${ }^{\mathrm{ZHII} / \mathrm{ZHI}}$ mice develop neurological symptoms at 13-21 months and survive 18-24 months (Rossi et al., 2001). Also in these mice, intercross with tg640 mice delayed onset of disease, prolonged survival (Table 1, Fig. $4 b, d$ ), and repressed axon-myelin degeneration (Fig. $4 m-p$ ), adding support to the hypothesis that $\mathrm{Dpl}$ and $\Delta \mathrm{PrP}$ share the same pathological basis. However, expression of the MBP-PrP transgene did not rescue Purkinje cell degeneration (Fig. $4 k, l$ ).

\section{Neuronal PrP ${ }^{\mathrm{C}}$ expression antagonizes CGC degeneration but does not prevent leukoencephalopathy}

Neuronal processes may conceivably represent the primary target of mutant PrP toxicity, whereas myelinopathy may be secondary to axonal degeneration. If so, oligodendrocytes may provide $\mathrm{PrP}^{\mathrm{C}}$ to the axon-myelin interface, which would abrogate any cell-autonomous axonal $\Delta \mathrm{PrP}$ toxicity in trans. Intercellular transfer of glycosylphosphatidylinositol (GPI)-anchored protein (a phenomenon called "cell painting") was described for CD4 (Anderson et al., 1996) and for $\operatorname{PrP}^{\mathrm{C}}$ in vitro (Liu et al., 2002). Alternatively, $\operatorname{PrP}^{\mathrm{C}}$ may act as a ligand and trigger signaling through receptors expressed by neighboring cells.

These scenarios were tested by crossing $\Delta \mathrm{PrP}^{\circ}$ mice with mice 

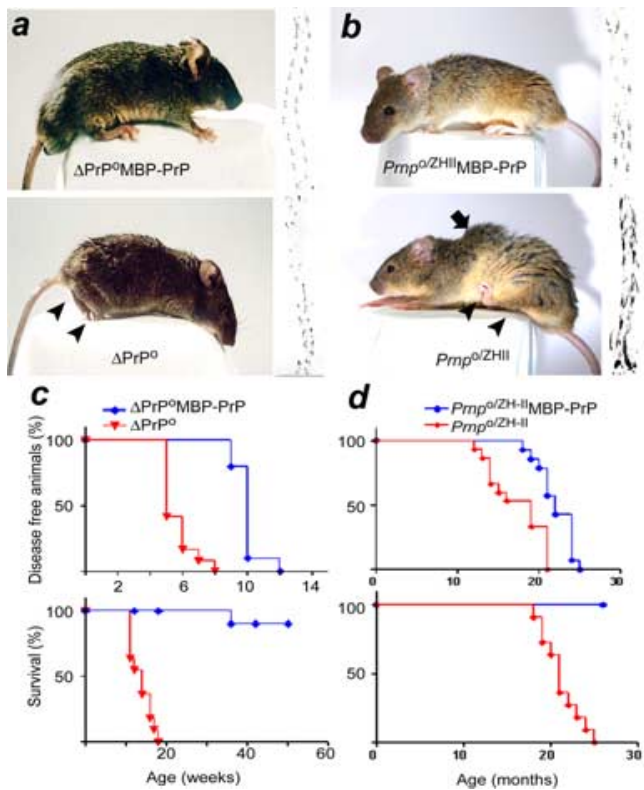

$\triangle$ PrPOMBP-PrP
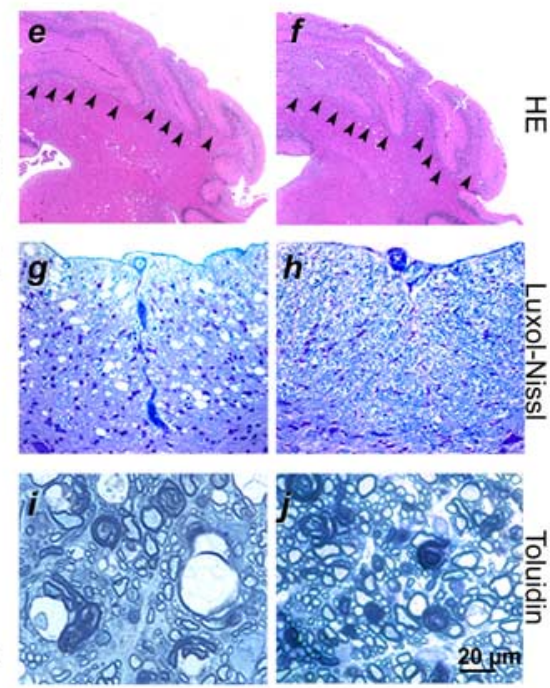
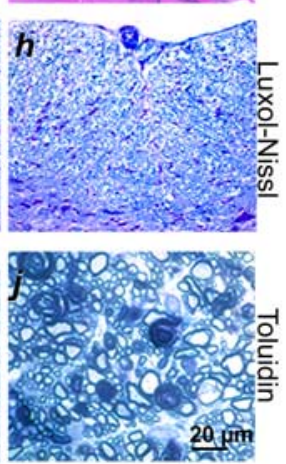

Prnpo/ZHII
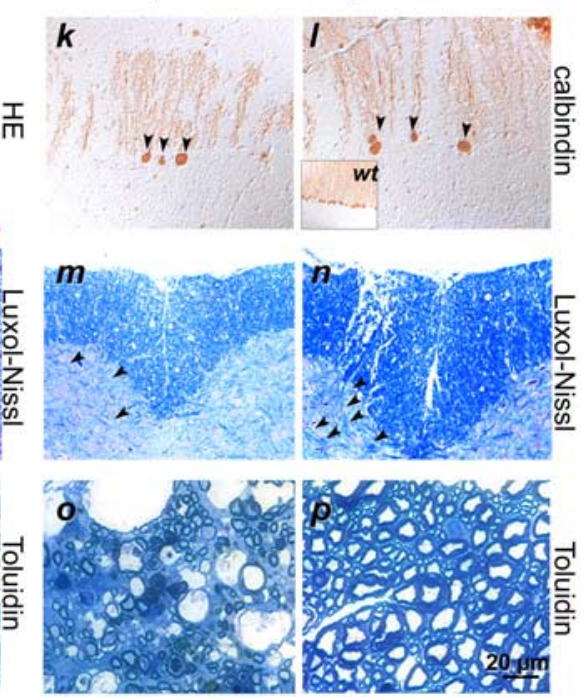

Figure 4. Oligodendroglial $\operatorname{PrP}{ }^{C}$ delays disease onset and represses leukoencephalopathy in $\Delta \operatorname{PrP}$ and $\operatorname{Prn} p^{\text {ZHII/o}}$ mice. Hindlimb spastic paralysis resulting in pathological posture of $\Delta \operatorname{PrP}^{\circ}\left(\boldsymbol{a}_{\text {, }}\right.$ 4 month old) and Prnp ${ }^{0 / Z H I I}\left(\boldsymbol{b}, 20\right.$ month old) mice (arrowheads), which was suppressed in age-matched littermates expressing additional MBP-PrP ${ }^{C}(\boldsymbol{a}, \boldsymbol{b})$. Prominent hunchback (arrow) frequently developed in $\Delta \mathrm{PrP}^{\circ}$ mice but was never seen in $\Delta \mathrm{PrP}^{0} \mathrm{MBP}$-PrP littermates. Gait impairment differences between $\mathrm{MBP}-\mathrm{PrP} \mathrm{P}^{0 / 0}-$ and $\mathrm{MBP}$-PrP ${ }^{+/ 0}$ mice were evidenced by inspection of ink footprints (right side of $\boldsymbol{a}, \boldsymbol{b}) . \boldsymbol{c}, \boldsymbol{d}$, Delayed ataxia and tremor onset $(p<0.0001)$ as well as enhanced survival $(p<0.0001)$ in $\Delta$ PrP $^{0}$ and Prnp ${ }^{2 H I I / 0}$ animals expressing MBP-PrP. Oligodendrocyte-specific PrP ${ }^{C}$ expression did not rescue degeneration of $\mathrm{CGC}$ in $\Delta \operatorname{PrP}^{0}(\boldsymbol{e}, \boldsymbol{f})$ mice or of Purkinje cells in Prnp ${ }^{\text {ZHII/o }}$ mice $(\boldsymbol{k}, \boldsymbol{I})$. Subtotal CGC layer loss (arrows) was visible in 4-month-old $\Delta \operatorname{PrP}^{\circ}$ mice regardless of MBP-PrP expression $(\boldsymbol{e}, \boldsymbol{f})$. Similar densities of residual Purkinje cells (arrows) were detected in 18 -month-old MBP-PrP ${ }^{+/ 0}(\boldsymbol{k})$ and MBP-PrP ${ }^{0 / 0}(\boldsymbol{I})$ littermates. In contrast, MBP-PrP efficiently repressed white-matter pathology $(\boldsymbol{g}-\boldsymbol{j}, \boldsymbol{m}-\boldsymbol{p})$. Intact myelin and no vacuolation were visible in the spinal white matter of a $\Delta$ PrP ${ }^{\circ} \mathrm{MBP}-\mathrm{PrP}$ mouse $(\boldsymbol{h})$, whereas a terminally sick $\triangle \operatorname{PrP}^{0}$ littermate $(\boldsymbol{g})$ displayed advanced degeneration with abundant vacuolation and subtotal myelin loss. Toluidine blue-stained semithin sections showed degenerated myelin spheroids but no vacuolation and increased numbers of large-caliber axons in MBP-PrP ${ }^{+}$mice $(j)$ compared with MBP-PrP ${ }^{0 / 0}$ mice (i). White-matter disease was also repressed in Dpl-expressing Prnp ${ }^{\mathrm{ZHII} / 0}$ mice $(\boldsymbol{m}-\boldsymbol{p})$, with no axon-myelin degeneration detectable in semithin sections $(\boldsymbol{p})$. Note the increased density of myelinated fibers entering the anterior horn of the spinal cord in MBP-PrP ${ }^{+/ 0}$ mice ( $\boldsymbol{m}, \boldsymbol{n}$, arrowheads). HE, Hematoxylin-eosin stain.

Table 1. Genetic, clinical, and histopathological features of $\Delta$ PrP- and Dpl-induced diseases

\begin{tabular}{|c|c|c|c|c|c|}
\hline Name & Genotype & Age at disease onset (days) & Survival (days) & Neuronal degeneration & White-matter disease \\
\hline$\Delta \mathrm{PrP}^{+}$ & $\mathrm{Hg}-\operatorname{PrP}(\Delta 32-134) ; \operatorname{Prnp}^{+/ 0}$ & No disease $(n=11)$ & $>600$ & None & None \\
\hline$\Delta \operatorname{PrP}^{0}$ & $\mathrm{Hg}-\operatorname{PrP}(\Delta 32-134) ; \operatorname{Prnp}^{0 / 0}$ & $43 \pm 2(n=11)$ & $99 \pm 5.3$ & $\begin{array}{l}\text { Full CGC degeneration at } 3 \\
\text { months }\end{array}$ & Severe at 3 months \\
\hline MBP-PrP & Prnp ${ }^{0 / 0} ;$ MBP-PrPtg $/-$ & No disease $(n=11)$ & $>600$ & None & None \\
\hline NSE-PrP & Prnp ${ }^{0 / 0} ;$ NSE-PrPtg/- & No disease $(n=12)$ & $>600$ & None & None \\
\hline$\Delta \mathrm{PrP}^{0} \mathrm{MBP}-\mathrm{PrP}$ & $\mathrm{Hg}-\operatorname{PrP}(\Delta 32-134) ; \operatorname{Prnp}^{0 / 0} ; M B P-\operatorname{PrP}{ }^{\mathrm{tg} /-}$ & $74 \pm 2(n=12) ; p<0.0001^{*}$ & $>400 ; p<0.0001$ & $\begin{array}{l}\text { Full CGC degeneration at } 3 \\
\text { months }\end{array}$ & Mild and stable \\
\hline$\Delta$ PrPoNSE-PrP & $\mathrm{Hg}-\operatorname{PrP}(\Delta 32-134) ; \operatorname{Prn} p^{0 / 0} ;$ NSE-PrPtg/- & $418 \pm 30(n=10) ; p<0.0001$ & $>600 ; p<0.0001$ & $\begin{array}{l}\text { Partial CGC degeneration at } \\
8-20 \text { months }\end{array}$ & Severe at $8-20$ months \\
\hline Prnp ${ }^{\mathrm{ZHII} /+}$ & Heterozygous Prnp ${ }^{\mathrm{ZHII}} ;$ overexpresses Dpl & None $(n=7)$ & $>700$ & None & None \\
\hline Prnp $p^{\text {ZHII/ZHII }}$ & ZHI/ZHII Prnp alleles; deficient in PrPC & $540 \pm 30(n=14)$ & $630 \pm 2.1$ & Purkinje cell degeneration & Severe at $18-22$ months \\
\hline $\operatorname{Prnp}^{Z \mathrm{ZH} / \mathrm{ZHII}} ; \mathrm{MBP}-\operatorname{PrP}$ & ZHI/ZHII; Prnp ${ }^{0 / 0} ; \mathrm{MBP}-P r P^{+/-}$ & $660 \pm 17.4(n=15) ; p<0.005$ & $>700 ; p<0.0001$ & Purkinje cell degeneration & Mild and stable \\
\hline
\end{tabular}

Significance $p$ values were derived by comparing mean survival or disease onset times of transgenic and control mice (unpaired Student's $t$ test).

expressing murine $\mathrm{PrP}^{\mathrm{C}}$ under transcriptional control of the NSE promoter (Fig. 5a). NSE-PrP were crossed to mice lacking Prnp, thus yielding NSE-PrP $\mathrm{P}^{\mathrm{tg} /-} \operatorname{Prnp}^{\mathrm{o} / \mathrm{o}}$ mice that are hemizygous for the NSE-PrP transgene and homozygous for the ZHI Prnp null allele. The latter mice (henceforth termed NSE-PrP ${ }^{\circ}$ ) express $\operatorname{PrP}^{\mathrm{C}}$ in neurons including CGC at higher levels than wild-type mice and do not develop any spontaneous pathological phenotype (O. T. Giger, B. Navarro, and A. Aguzzi, unpublished data). Instead, $\Delta \mathrm{PrP}^{\circ} \mathrm{NSE}-\mathrm{PrP}$ mice developed tremor and ataxia only at 9-18 months and survived $>500 \mathrm{~d}$. This confirms that neuronal $\mathrm{PrP}^{\mathrm{C}}$ expression prolongs survival of $\Delta \mathrm{PrP}^{\circ}$ mice (Table 1 , Fig. $5 b)$. However, histological analysis of clinically sick animals revealed leukoencephalopathy of similar severity in $\Delta \mathrm{PrP}^{\circ}$ and $\Delta \mathrm{PrP}^{\circ} \mathrm{NSE}-\mathrm{PrP}$ mice but not in age-matched $\Delta \mathrm{PrP}^{+}$animals (Fig. $5 c-h$ ). Leukoencephalopathy was found also in pyramidal tracts, corpus callosum, and optic tracts (data not shown), suggesting that neuronal protection, by prolonging survival, allowed for more extensive development of myelin pathology.

These findings indicate that neuron-restricted expression, even at supraphysiological levels, does not suffice to prevent $\Delta \mathrm{PrP}$-induced leukoencephalopathy and adds strength to the contention that $\Delta \mathrm{PrP}^{\circ}$ leukoencephalopathy is a primary myelin pathology. $\Delta \mathrm{PrP}^{\circ} \mathrm{NSE}-\mathrm{PrP}$ mice suffered also from CGC degeneration, although to a lesser extent than $\Delta \mathrm{PrP}^{\circ}$ mice. This sug- 


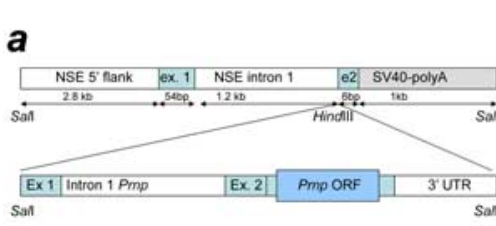

b
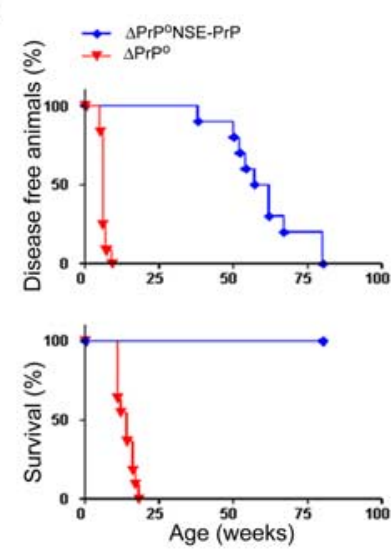
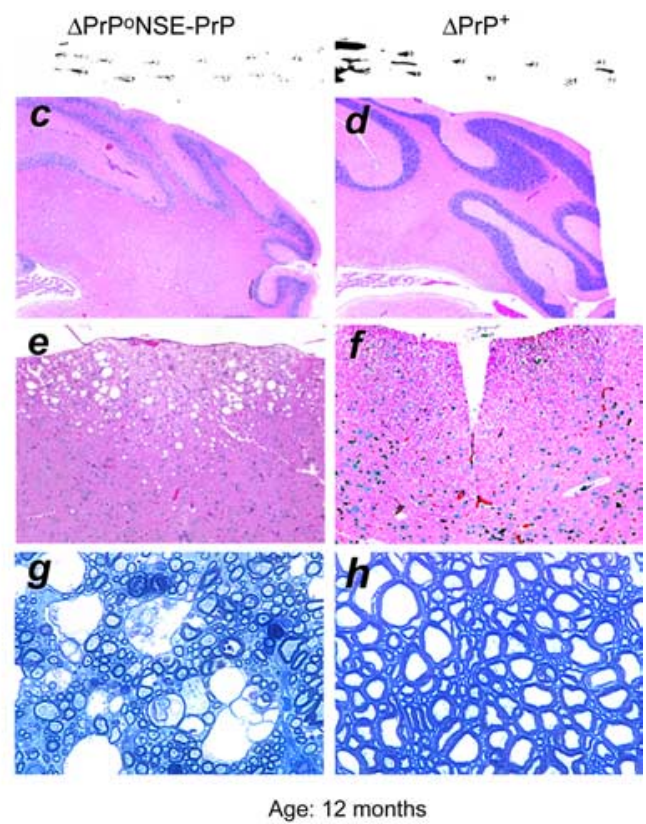

Figure 5. Neuronal PrPC delays disease onset and rescues survival but does not prevent axon-myelin degeneration. $\boldsymbol{a}$, Schematic drawing of the DNA construct used to generate NSE-PrP transgenic mice. $\boldsymbol{b}$, Neuron-specific wild-type PrP ${ }^{C}$ expression delayed onset of ataxia and tremor in $\Delta \operatorname{PrP}^{\circ}$ mice for long periods $(p<0.0001)$ but did not entirely prevent disease. CGC rescue in $\Delta \mathrm{PrP}^{0} \mathrm{NSE}-\mathrm{PrP}$ transgenic mice $(\boldsymbol{c})$ was less than in $\Delta \mathrm{PrP}^{+}$mice $(\boldsymbol{d})$, yet residual granule cells at 12 months of age were indicative of decelerated CGC degeneration. Instead, spinal white matter underwent degeneration similarly to $\Delta \operatorname{PrP}^{\circ}$ animals with vacuolation and axonal loss $(\boldsymbol{e}, \boldsymbol{g})$, in contrast to $\Delta \mathrm{PrP}^{+}$mice $(\boldsymbol{f}, \boldsymbol{h})$. Ink footprints over cand $\boldsymbol{d}$ (obtained as in Fig. 4) indicate that ataxic gait of $\Delta \operatorname{PrP}^{0}$ mice was suppressed to a similar extent by the wild-type Prnp ${ }^{+}$allele and the NSE-PrP transgene.

gests that neuron-restricted expression of $\operatorname{PrP}^{\mathrm{C}}$ is beneficial but insufficient to completely prevent neuronal death (Fig. $5 c, d$ ) and raises the possibility that CGC may suffer (at least in part) from deafferentation after degeneration of white-matter fibers innervating the granule cell layer.

\section{$\operatorname{PrP}^{\mathrm{C}}$ is present in purified myelin of wild-type and MBP-PrP mice}

Myelin was isolated from brains of NSE-PrP ${ }^{\circ}, \mathrm{MBP} \mathrm{PrP}^{\circ}$, $\operatorname{Prn} p^{\mathrm{o} / \mathrm{o}}, \Delta \operatorname{PrP}^{\mathrm{o}}$, and $\operatorname{Prnp}{ }^{+/+}$(wild-type) mice (age, 2-3 months). Sizable amounts of $\operatorname{PrP}^{\mathrm{C}}$ were detected in myelin preparations of $\operatorname{Prnp}^{+/+}, \mathrm{MBP}-\mathrm{PrP}$, and $\Delta \mathrm{PrP}^{\circ}$ mice (Fig. 6a). However, we found $\operatorname{PrP}^{\mathrm{C}}$ also in purified myelin of NSE-PrP mice, whose oligodendrocytes do not express $\mathrm{PrP}^{\mathrm{C}}$ (Fig. 6a,d). Poor fractionation with neuronal or astrocytic components contaminating the myelin preparations appears to be very unlikely, because GFAP and NCAM, which would be indicative of contamination, were essentially removed (Fig. $6 b, c$ ). The $120 \mathrm{kDa}$ isoform of NCAM is the major isoform found in oligodendrocytes and myelin sheaths (Bhat and Silberberg, 1988). Intriguingly, $\Delta \mathrm{PrP}$ brain homogenates displayed prominent NCAM 180, as well as two additional NCAM bands of unknown origin, which will be characterized in future studies. The presence of $\operatorname{PrP}^{\mathrm{C}}$ in myelin of NSE-PrP mice, therefore, suggests that axolemmal PrP undergoes high-affinity interactions with myelin membrane proteins, as shown for other proteins of the myelin-axolemmal complex (Menon et al., 2003). Alternatively, neuronally synthesized $\operatorname{PrP}^{\mathrm{C}}$ may be transferred onto myelin sheaths by cell painting, which was shown to be highly efficient in the case of GPI-linked proteins (Anderson et al., 1996).

Unglycosylated $\mathrm{PrP}^{\mathrm{C}}$ seems to be predominant in myelinic $\operatorname{PrP}^{\mathrm{C}}$ (Fig. 6a), similarly to what was observed in MBP-PrP mice (Prinz et al., 2004). The intense low-molecular-weight $\operatorname{PrP}^{\mathrm{C}}$ bands in MBP-PrP mice might reflect degradation of unglycosylated $\operatorname{PrP}^{\mathrm{C}}$, because glycosylation is known to influence the stability of proteins.

\section{$\Delta \mathrm{PrP}$ and $\mathrm{PrP}^{\mathrm{C}}$ in MBP-PrP mice are localized in lipid rafts}

$\operatorname{PrP}^{\mathrm{C}}$ localizes to lipid rafts (Naslavsky et al., 1997; Meier et al., 2003), in which it may exert a physiological function by interacting with signaling molecules. Dpl is also found in rafts (Massimino et al., 2004). If toxicity of $\Delta \mathrm{PrP}$ and Dpl results from interference with some $\operatorname{PrP}^{\mathrm{C}}$ mediated signaling pathway and toxicity is counteracted by $\operatorname{PrP}^{\mathrm{C}}$, these three proteins may compete for the same partners on rafts. Moreover, $\Delta \mathrm{PrP}$ and $\mathrm{Dpl}$ may disrupt normal axon-glia interaction and adhesion, whose integrity depends on GPIanchored and transmembrane proteins (Falk et al., 2002; Marcus et al., 2002; Bartsch, 2003; Vinson et al., 2003). To investigate the topology of $\Delta \mathrm{PrP}$, we performed flotation assays on Optiprep gradients with cold Triton $\mathrm{X}-100$-treated $\Delta \mathrm{PrP}^{\circ}$ brain extracts. $\Delta \mathrm{PrP}$ was detected in lowdensity, detergent-insoluble fractions and displayed buoyancy similar to that of $\operatorname{PrP}$ and flotillin (Fig. $6 f-j$ ). These characteristics strongly suggest that $\Delta \mathrm{PrP}$ is indeed localized in lipid rafts and colocalized with wild-type $\operatorname{PrP}^{\mathrm{C}}$. Therefore, cytotoxicity is unlikely to be attributable to inappropriate membrane targeting of $\Delta$ PrP. In addition, $\operatorname{PrP}^{\mathrm{C}}$ from MBP-PrP mice associated with rafts similarly to $\operatorname{PrP}^{\mathrm{C}}$ from wild-type mice (Fig. 6i). Unglycosylated $\operatorname{PrP}^{\mathrm{C}}$ was the dominant moiety, similar to $\operatorname{PrP}^{\mathrm{C}}$ isolated from myelin.

\section{Neither $\Delta \mathrm{PrP}$ nor $\mathrm{Dpl}$ affect myelin protein expression}

Leukoencephalopathy in $\Delta \mathrm{PrP}^{\mathrm{o}}$ and $\operatorname{Prn} p^{\mathrm{ZHII} / \mathrm{o}}$ mice had features suggestive of compromised axon-glial adhesion similar to those described in mice lacking MAG and myelin galactolipids (Marcus et al., 2002), as well as in mice deficient for PLP (Griffiths et al., 1998). In addition, we found axonal swellings similar to those of Cnp1 ${ }^{-1-}$ mice (Lappe-Siefke et al., 2003). Moreover, in mice deficient for these diverse myelin proteins, oligodendrocytes produce appropriately thick myelin sheaths. These findings raised the question as to whether $\Delta \operatorname{PrP}$ and Dpl might affect the synthesis or the stability of the above myelin components. Therefore, we analyzed the myelin content in whole brain and spinal cord homogenates of $\operatorname{Prnp}^{\mathrm{o} / \mathrm{o}}, \operatorname{Prnp}^{+/+}, \Delta \mathrm{PrP}^{\mathrm{o}}$, and Prnp ${ }^{\mathrm{ZHII} / \mathrm{o}}$ mice (age, 2 months). MAG, MBP, PLP, and CNP transcription and protein content were assayed with Northern and Western blots (Fig. $7 a, b$ ). The amount of MAG and MBP protein was normalized against actin (Fig. $7 c$ ). These analyses revealed that both the transcription and the steady-state protein concentration of all investigated myelin proteins were unchanged in $\Delta \mathrm{PrP}^{\circ}$ and Prn$p^{\mathrm{ZHII} / \mathrm{o}}$ mice.

\section{Discussion}

Overexpression of amino proximally truncated $\operatorname{PrP}^{\mathrm{C}}$ variants collectively termed $\Delta \operatorname{PrP}$, (Shmerling et al., 1998), or of the structural $\mathrm{PrP}^{\mathrm{C}}$ homolog Dpl (Weissmann and Aguzzi, 1999; Behrens 

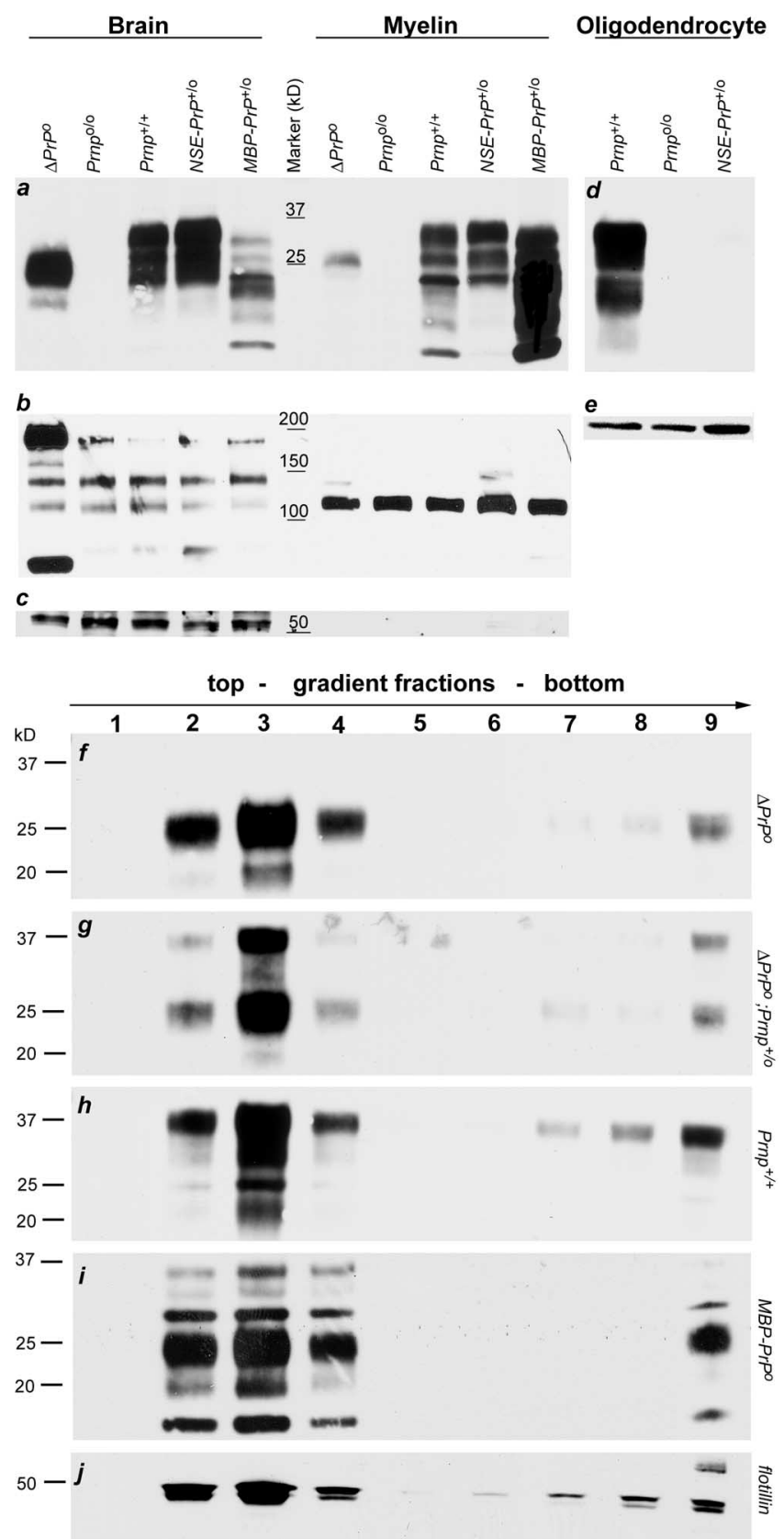

Figure 6. $\operatorname{PrP}{ }^{C}$ and $\Delta P r P$ are present in purified myelin and detergent-insoluble membrane fractions. PrP ${ }^{C}$ expression was analyzed by Western blotting of brain homogenates, myelin preparations, and cultured oligodendrocyte lysates of various genotypes. $a$, Brain homogenate (10 $\mu \mathrm{g}$ ) or 5 $\mu \mathrm{g}$ of myelin were loaded in each lane. Myelin preparations were analyzed for impurities by neural cell adhesion molecule (anti-NCAM, $\boldsymbol{b}$ ) and an astrocytic component (anti-GFAP, $\boldsymbol{c}$ ). $\boldsymbol{d}$, Equal protein amounts of oligodendrocyte lysates of wild-type, $\operatorname{Prnp}^{0 / 0}$, and NSE-PrP mice were loaded. $\boldsymbol{e}, \beta$-Actin was visualized as a loading control. Optiprep fractions of Triton X-100-treated cerebral homogenates were analyzed for $\operatorname{PrP}^{C}$ expression on immunoblots. $\Delta \operatorname{PrP}^{\circ}(\boldsymbol{f}), \Delta \operatorname{PrP}^{0}, \operatorname{Prnp}^{+/ 0}(\boldsymbol{g}), \operatorname{Prnp}^{+/+}(\boldsymbol{h})$, and $M B P-\operatorname{PrP}^{\circ}(\boldsymbol{i})$ tissues were analyzed. $\boldsymbol{j}$, Detection of flotillin, a $48 \mathrm{kDa}$ marker protein of lipid rafts. Truncated $\operatorname{PrP} C^{C}$ was primarily localized in the high-density, detergent-insoluble fraction, indicating its presence in membrane rafts.

et al., 2002), triggers neuronal degeneration. We now report that both $\Delta \mathrm{PrP}$ and Dpl elicit additional leukoencephalopathy. These pathologies were not entirely expected, because PrP-related diseases are thought to affect primarily neurons (Chiesa et al., 1998, 2000; Hegde et al., 1998, 1999; Shmerling et al., 1998; Rossi et al., 2001). Conversely, myelin sheath damage and neuroaxonal dys- trophy (Liberski et al., 2002), as well as cytopathic changes in oligodendrocytes (El Hachimi et al., 1998), have been noted in human and animal TSEs.

Myelinopathy, rather than neuronal damage, may be a major determinant of lethality in Shmerling's syndrome, because oligodendrocyte-restricted expression of $\mathrm{PrP}^{\mathrm{C}}$ selectively suppresses leukoencephalopathy and restores long-term survival. Instead, neuron-restricted expression of $\mathrm{PrP}^{\mathrm{C}}$, even at supraphysiological levels, does not prevent white-matter degeneration. These data indicate that leukoencephalopathy is not just a consequence of neurodegeneration but suggest a primary role of oligodendrocytes in white-matter disease. Oligodendrocyte-restricted $\mathrm{PrP}^{\mathrm{C}}$ may repress in trans the axonal pathology elicited by mutant PrP. A cellular signal might be transduced through $\mathrm{PrP}^{\mathrm{C}}$ from oligodendrocytes to axons, analogously to other GPIanchored proteins (such as F3 and NCAM 120) that play a role in axon-myelin interactions (Falk et al., 2002). Because $\operatorname{PrP}^{\mathrm{C}}$ binds in vitro to the transmembrane and GPI-linked forms of NCAM (Schmitt-Ulms et al., 2001), it might contribute to the very same pathways. Alternatively, $\operatorname{PrP}^{\mathrm{C}}$ may instruct oligodendrocytes to release factors necessary for axonal survival (Wilkins et al., 2003). Direct toxicity of $\Delta \mathrm{PrP}$ and $\mathrm{Dpl}$ to oligodendrocytes seems to be unlikely, because we did not observe oligodendrocytic cell death or ultrastructural abnormalities in oligodendrocytes. Both oligodendrocyte- and neuron-restricted expression delayed the clinical course of Shmerling's disease, yet only endogenous $\mathrm{PrP}^{\mathrm{C}}$ expression, which occurs on both neurons and glia (Moser et al., 1995), brought about complete rescue. Therefore, both neuronal and oligodendrocyte $\operatorname{PrP}^{\mathrm{C}}$ expression are needed for maintenance of the axon-myelin interface in $\Delta \operatorname{PrP}$ mice.

Surprisingly, neuron-specific $\operatorname{PrP}^{\mathrm{C}}$ expression, even at supraphysiological levels, did not completely rescue CGC degeneration. Perhaps ongoing degeneration of white-matter fibers innervating the granule cell layer participates indirectly in granule cell degeneration, e.g., by deafferentation and neuronal "dying back." The delayed onset of myelinopathy in $\Delta \operatorname{PrP}^{\circ} \mathrm{NSE}-\mathrm{PrP}$ mice might be related to the presence of $\mathrm{PrP}^{\mathrm{C}}$ in NSE-PrP myelin which, in turn, might be attributable to GPI cell painting or to high-affinity interaction of axonal $\operatorname{PrP}^{\mathrm{C}}$ with myelin components.

Leukoencephalopathy in $\Delta \mathrm{PrP}^{\circ}$ and $\operatorname{Pr} n p^{\mathrm{ZHII} / \mathrm{o}}$ mice had features suggestive of compromised axon-glial adhesion, including axonal swellings similar to those described in mice lacking MAG and myelin galactolipids (Marcus et al., 2002), PLP (Griffiths et al., 1998), and Cnp1 (Lappe-Siefke et al., 2003). However, expression of MAG, MBP, PLP, and CNP was not affected in $\triangle \operatorname{PrP}^{\circ}$ and $\operatorname{Prnp}{ }^{\mathrm{ZHII} / \mathrm{o}}$ mice, suggesting that disturbance of myelin and axonal physiology is directly mediated by $\Delta \mathrm{PrP}$ and $\mathrm{Dpl}$ rather than by dysmetabolism of myelin proteins.

The overlapping patterns of (1) Dpl- and $\Delta \mathrm{PrP}$-induced leukoencephalopathy, (2) their modulation by coexpression of fulllength $\operatorname{PrP}^{\mathrm{C}}$ (Moore et al., 1999; Li et al., 2000; Rossi et al., 2001), (3) the structural homology between Dpl and $\Delta \operatorname{PrP}$ (Luhrs et al., 2003), and (4) the abrogation of neurodegeneration by removal of Dpl from Prnp ${ }^{\mathrm{ZHII} / \mathrm{ZHII}}$ mice (Genoud et al., 2004) all suggest that $\Delta \mathrm{PrP}$ and $\mathrm{Dpl}$ trigger similar pathogenetic mechanisms. What might be the common structural basis of such pathologies? Of all amino proximal deletions that were tested (Shmerling et al., 1998), only those that disrupt the highly conserved hydrophobic TM1 region (amino acids 113-134) provoked pathologies that were prevented by wild-type $\operatorname{PrP}^{\mathrm{C}}$.

Two possible molecular mechanism of toxicity have been put forward. Shmerling et al. (1998) proposed that the amino proximal region of PrP represents an effector domain, whose deletion 
a
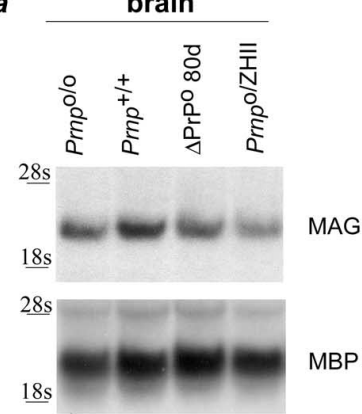

$2 \underline{8 \mathrm{~s}}$

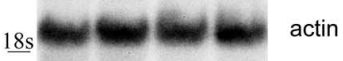

$b$

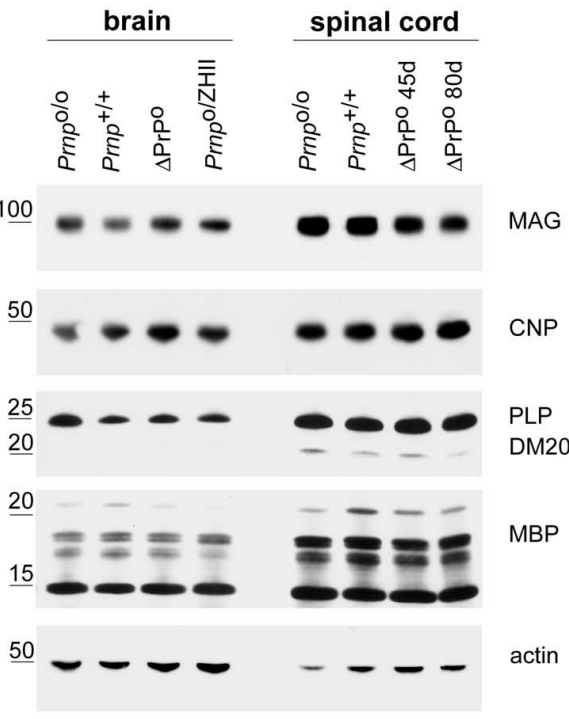

$c$

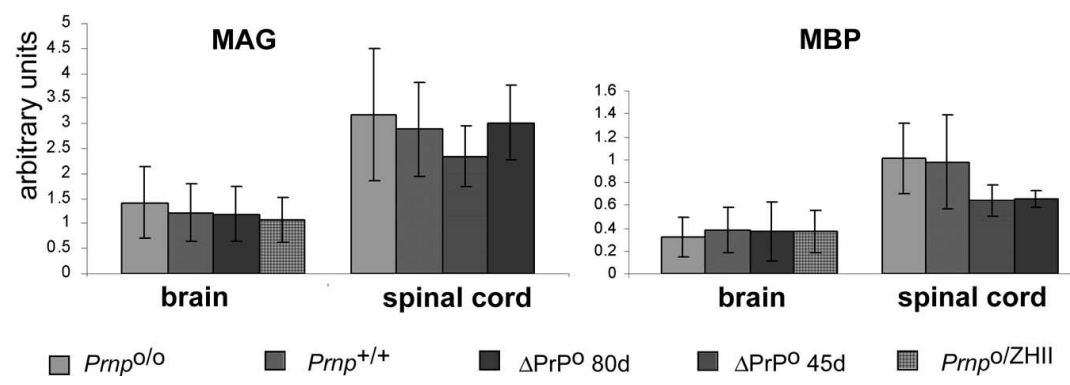

Figure 7. Synthesis and stability of myelin components are not affected by $\Delta \mathrm{PrP}$ and Dpl. Brain and spinal cord homogenates from 2-month-old Prnp ${ }^{0 / 0}, \operatorname{Prnp}^{+/+}, \Delta \operatorname{PrP}^{0}$, and Prnp ${ }^{\text {ZHII/0}}$ mice and 45 -d-old $\Delta \operatorname{PrP}^{\circ}$ mice were analyzed by Northern $(\boldsymbol{a})$ and Western (b) blotting. PLP/DM20, Proteolipid protein and its minor isoform; Actin, loading control. $\boldsymbol{c}$, Chemiluminescence signals for MAG and MBP were quantified by photon acquisition and normalized by relating them to actin signals. No significant $p$ values were derived by comparing mean protein expression levels of transgenic and control mice (unpaired Student's $t$ test).

abolishes trophic signaling and partially reduces the affinity of $\operatorname{PrP}^{\mathrm{C}}$ for its hypothetical ligands. According to this scenario, removal of the amino proximal confers recessive-negative toxic properties to $\Delta \operatorname{PrP}$ that are abolished if $\Delta \operatorname{PrP}$ is displaced by $\operatorname{PrP}^{\mathrm{C}}$. In wild-type mice, oligodendrocytic $\operatorname{PrP}^{\mathrm{C}}$ might transduce survival signals by interacting with axonal molecules. Leukoencephalopathy may occur because $\Delta \operatorname{PrP}$ abrogates such trophic signals. The absence of such phenotype in $\operatorname{Prnp}^{-1-}$ mice suggests the existence of a functional homolog provisionally termed $\pi$ (Shmerling et al., 1998).

Alternatively, $\operatorname{PrP}^{\mathrm{C}}$ and its homologs may form homo- and hetero-oligomers. Although $\Delta \mathrm{PrP}$ and Dpl homo-oligomers may be toxic to neurons, participation of full-length $\mathrm{PrP}^{\mathrm{C}}$ to such complexes would "dope" their stoichiometry, hence abolishing their toxicity (Behrens and Aguzzi, 2002).

It will be interesting to test which of the above hypotheses, if any, reflects the mechanism of $\Delta \mathrm{PrP} / \mathrm{Dpl}$-associated damage to the axonmyelin complex. The finding that full-length prion protein, specifically expressed in oligodendrocytes and found in myelin, represses these defects suggests that $\operatorname{PrP}^{\mathrm{C}}$ plays a role in myelin physiology, oligodendroglial-mediated axonal support, and axon-myelin interactions. This contention is supported by the finding that aged $\operatorname{Prnp}^{-1-}$ mice suffer from peripheral demyelination. Both leukoencephalopathy and CGC degeneration are suppressed by coexpression of $\operatorname{PrP}^{\mathrm{C}}$, suggesting that the molecular pathogenesis of these two diseases is similar.
In addition to its role in prion disease pathogenesis, repression of $\Delta \mathrm{PrP} / \mathrm{Dpl}-$ associated neurodegenerative pathologies is likely to represent the most thoroughly characterized function of $\operatorname{PrP}^{\mathrm{C}}$. As shown by the present study, the neurodegenerative syndromes induced by $\Delta \mathrm{PrP}$ provide an accessible experimental system for studying function of $\operatorname{PrP}^{\mathrm{C}}$ in vivo by reverse genetics.

\section{References}

Aguzzi A, Polymenidou M (2004) Mammalian prion biology. One century of evolving concepts. Cell 116:313-327.

Anderson SM, Yu G, Giattina M, Miller JL (1996) Intercellular transfer of a glycosylphosphatidylinositol (GPI)-linked protein: release and uptake of CD4-GPI from recombinant adeno- associated virus-transduced HeLa cells. Proc Natl Acad Sci USA 93:5894-5898.

Bartsch U (2003) Neural CAMS and their role in the development and organization of myelin sheaths. Front Biosci 8:d477-d490.

Behrens A, Aguzzi A (2002) Small is not beautiful: antagonizing functions for the prion protein $\operatorname{PrP}(\mathrm{C})$ and its homologue Dpl. Trends Neurosci 25:150-154.

Behrens A, Genoud N, Naumann H, Rulicke T, Janett F, Heppner FL, Ledermann B, Aguzzi A (2002) Absence of the prion protein homologue Doppel causes male sterility. EMBO J 21:3652-3658.

Bhat S, Silberberg D (1988) Developmental expression of neural cell adhesion molecules of oligodendrocytes in vivo and in culture. J Neurochem 50:1830-1838.

Bounhar Y, Zhang Y, Goodyer CG, LeBlanc A (2001) Prion protein protects human neurons against Bax-mediated apoptosis. J Biol Chem 276:39145-39149.

Brandner S, Isenmann S, Raeber A, Fischer M, Sailer A, Kobayashi Y, Marino S, Weissmann C, Aguzzi A (1996) Normal host prion protein necessary for scrapie-induced neurotoxicity. Nature 379:339-343.

Brown DR, Qin K, Herms JW, Madlung A, Manson J, Strome R, Fraser PE, Kruck T, von Bohlen A, Schulz-Schaeffer W, Giese A, Westaway D, Kretzschmar H (1997) The cellular prion protein binds copper in vivo. Nature 390:684-687.

Büeler HR, Fischer M, Lang Y, Bluethmann H, Lipp HP, DeArmond SJ, Prusiner SB, Aguet M, Weissmann C (1992) Normal development and behaviour of mice lacking the neuronal cell-surface PrP protein. Nature 356:577-582.

Büeler HR, Aguzzi A, Sailer A, Greiner RA, Autenried P, Aguet M, Weissmann C (1993) Mice devoid of PrP are resistant to scrapie. Cell 73:1339-1347.

Caughey B, Brown K, Raymond GJ, Katzenstein GE, Thresher W (1994) Binding of the protease-sensitive form of $\operatorname{PrP}$ (prion protein) to sulfated glycosaminoglycan and congo red [corrected]. J Virol [Erratum (1994) 68:4107] 68:2135-2141.

Chiarini LB, Freitas AR, Zanata SM, Brentani RR, Martins VR, Linden R (2002) Cellular prion protein transduces neuroprotective signals. EMBO J 21:3317-3326.

Chiesa R, Piccardo P, Ghetti B, Harris DA (1998) Neurological illness in transgenic mice expressing a prion protein with an insertional mutation. Neuron 21:1339-1351.

Chiesa R, Drisaldi B, Quaglio E, Migheli A, Piccardo P, Ghetti B, Harris DA (2000) Accumulation of protease-resistant prion protein $(\mathrm{PrP})$ and apoptosis of cerebellar granule cells in transgenic mice expressing a PrP insertional mutation. Proc Natl Acad Sci USA 97:5574-5579.

Colling SB, Khana M, Collinge J, Jefferys JG (1997) Mossy fibre reorganization in the hippocampus of prion protein null mice. Brain Res 755:28-35.

Collinge J, Whittington MA, Sidle KC, Smith CJ, Palmer MS, Clarke AR, 
Jefferys JG (1994) Prion protein is necessary for normal synaptic function. Nature 370:295-297.

El Hachimi KH, Chaunu MP, Brown P, Foncin JF (1998) Modifications of oligodendroglial cells in spongiform encephalopathies. Exp Neurol 154:23-30.

Falk J, Bonnon C, Girault JA, Faivre-Sarrailh C (2002) F3/contactin, a neuronal cell adhesion molecule implicated in axogenesis and myelination. Biol Cell 94:327-334.

Fischer M, Rülicke T, Raeber A, Sailer A, Moser M, Oesch B, Brandner S, Aguzzi A, Weissmann C (1996) Prion protein (PrP) with aminoproximal deletions restoring susceptibility of PrP knockout mice to scrapie. EMBO J 15:1255-1264.

Genoud N, Behrens A, Miele G, Robay D, Heppner FL, Freigang S, Aguzzi A (2004) Disruption of Doppel prevents neurodegeneration in mice with extensive Prnp deletions. Proc Natl Acad Sci USA 101:4198-4203.

Griffiths I, Klugmann M, Anderson T, Yool D, Thomson C, Schwab MH, Schneider A, Zimmermann F, McCulloch M, Nadon N, Nave KA (1998) Axonal swellings and degeneration in mice lacking the major proteolipid of myelin. Science 280:1610-1613.

Hegde RS, Mastrianni JA, Scott MR, DeFea KA, Tremblay P, Torchia M, DeArmond SJ, Prusiner SB, Lingappa VR (1998) A transmembrane form of the prion protein in neurodegenerative disease. Science 279:827-834.

Hegde RS, Tremblay P, Groth D, DeArmond SJ, Prusiner SB, Lingappa VR (1999) Transmissible and genetic prion diseases share a common pathway of neurodegeneration. Nature 402:822-826.

Herms J, Tings T, Gall S, Madlung A, Giese A, Siebert H, Schurmann P, Windl O, Brose N, Kretzschmar H (1999) Evidence of presynaptic location and function of the prion protein. J Neurosci 19:8866-8875.

Hutter G, Heppner FL, Aguzzi A (2003) No superoxide dismutase activity of cellular prion protein in vivo. Biol Chem 384:1279-1285.

Kretzschmar HA, Tings T, Madlung A, Giese A, Herms J (2000) Function of $\operatorname{PrP}(\mathrm{C})$ as a copper-binding protein at the synapse. Arch Virol Suppl 16:239-249.

Kurschner C, Morgan JI, Yehiely F, Bamborough P, Da Costa M, Perry BJ, Thinakaran G, Cohen FE, Carlson GA, Prusiner SB (1995) The cellular prion protein $(\mathrm{PrP})$ selectively binds to $\mathrm{Bcl}-2$ in the yeast two-hybrid system: identification of candidate proteins binding to prion protein. Brain Res Mol Brain Res 30:165-168.

Kuwahara C, Takeuchi AM, Nishimura T, Haraguchi K, Kubosaki A, Matsumoto Y, Saeki K, Yokoyama T, Itohara S, Onodera T (1999) Prions prevent neuronal cell-line death. Nature 400:225-226.

Lappe-Siefke C, Goebbels S, Gravel M, Nicksch E, Lee J, Braun PE, Griffiths IR, Nave KA (2003) Disruption of Cnp1 uncouples oligodendroglial functions in axonal support and myelination. Nat Genet 33:366-374.

Li A, Sakaguchi S, Atarashi R, Roy BC, Nakaoke R, Arima K, Okimura N, Kopacek J, Shigematsu K (2000) Identification of a novel gene encoding a PrP-like protein expressed as chimeric transcripts fused to PrP exon 1/2 in ataxic mouse line with a disrupted PrP gene. Cell Mol Neurobiol 20:553-567.

Liberski P, Bratosiewicz-Wasik J, Gajdusek D, Brown P (2002) Ultrastructural studies of experimental scrapie and Creutzfeldt-Jakob disease in hamsters. I. Alterations of myelinated axons. Acta Neurobiol Exp (Wars) 62:121-129.

Liu T, Li R, Pan T, Liu D, Petersen RB, Wong BS, Gambetti P, Sy MS (2002) Intercellular transfer of the cellular prion protein. J Biol Chem 277:47671-47678.

Lledo PM, Tremblay P, Dearmond SJ, Prusiner SB, Nicoll RA (1996) Mice deficient for prion protein exhibit normal neuronal excitability and synaptic transmission in the hippocampus. Proc Natl Acad Sci USA 93:2403-2407.

Luhrs T, Riek R, Guntert P, Wuthrich K (2003) NMR structure of the human doppel protein. J Mol Biol 326:1549-1557.

Mallucci GR, Ratte S, Asante EA, Linehan J, Gowland I, Jefferys JG, Collinge J (2002) Post-natal knockout of prion protein alters hippocampal CA1 properties, but does not result in neurodegeneration. EMBO J 21:202-210.

Marcus J, Dupree JL, Popko B (2002) Myelin-associated glycoprotein and myelin galactolipids stabilize developing axo-glial interactions. J Cell Biol 156:567-577.

Massimino ML, Ballarin C, Bertoli A, Casonato S, Genovesi S, Negro A, Sorgato MC (2004) Human Doppel and prion protein share common membrane microdomains and internalization pathways. Int J Biochem Cell Biol 36:2026-2041.

McCarthy KD, de Vellis J (1980) Preparation of separate astroglial and oligodendroglial cell cultures from rat cerebral tissue. J Cell Biol 85:890-902.

Meier P, Genoud N, Prinz M, Maissen M, Rulicke T, Zurbriggen A, Raeber AJ,
Aguzzi A (2003) Soluble dimeric prion protein binds $\operatorname{PrP}(\mathrm{Sc})$ in vivo and antagonizes prion disease. Cell 113:49-60.

Menon K, Rasband MN, Taylor CM, Brophy P, Bansal R, Pfeiffer SE (2003) The myelin-axolemmal complex: biochemical dissection and the role of galactosphingolipids. J Neurochem 87:995-1009.

Miele G, MacRae L, McBride D, Manson J, Clinton M (1998) Elimination of false positives generated through PCR re-amplification of differential display cDNA. Biotechniques 25:138-144.

Moore RC, Lee IY, Silverman GL, Harrison PM, Strome R, Heinrich C, Karunaratne A, Pasternak SH, Chishti MA, Liang Y, Mastrangelo P, Wang K, Smit AF, Katamine S, Carlson GA, Cohen FE, Prusiner SB, Melton DW, Tremblay P, Hood LE, et al. (1999) Ataxia in prion protein (PrP)deficient mice is associated with upregulation of the novel PrP-like protein doppel. J Mol Biol 292:797-817.

Moser M, Colello RJ, Pott U, Oesch B (1995) Developmental expression of the prion protein gene in glial cells. Neuron 14:509-517.

Naslavsky N, Stein R, Yanai A, Friedlander G, Taraboulos A (1997) Characterization of detergent-insoluble complexes containing the cellular prion protein and its scrapie isoform. J Biol Chem 272:6324-6331.

Norton WT, Poduslo SE (1973) Myelination in rat brain: method of myelin isolation. J Neurochem 21:749-757.

Paitel E, Fahraeus R, Checler F (2003) Cellular prion protein sensitizes neurons to apoptotic stimuli through Mdm2-regulated and p53-dependent caspase 3-like activation. J Biol Chem 278:10061-10066.

Prinz M, Montrasio F, Furukawa H, van der Haar ME, Schwarz P, Rülicke T, Giger O, Häusler KG, Glatzel M, Aguzzi A (2004) Intrinsic resistance of oligodendrocytes to prion infection. J Neurosci 24:5974-5981.

Prusiner SB (1982) Novel proteinaceous infectious particles cause scrapie. Science 216:136-144.

Rieger R, Edenhofer F, Lasmezas CI, Weiss S (1997) The human 37-kDa laminin receptor precursor interacts with the prion protein in eukaryotic cells. Nat Med 3:1383-1388.

Rossi D, Cozzio A, Flechsig E, Klein MA, Aguzzi A, Weissmann C (2001) Onset of ataxia and Purkinje cell loss in PrP null mice inversely correlated with Dpl level in brain. EMBO J 20:1-9.

Sambrook J, Russell DW (2001) Molecular cloning: a laboratory manual, Ed 3. Cold Spring Harbor, NY: Cold Spring Harbor Laboratory.

Schmitt-Ulms G, Legname G, Baldwin MA, Ball HL, Bradon N, Bosque PJ, Crossin KL, Edelman GM, DeArmond SJ, Cohen FE, Prusiner SB (2001) Binding of neural cell adhesion molecules (N-CAMs) to the cellular prion protein. J Mol Biol 314:1209-1225.

Shmerling D, Hegyi I, Fischer M, Blattler T, Brandner S, Gotz J, Rulicke T, Flechsig E, Cozzio A, von Mering C, Hangartner C, Aguzzi A, Weissmann C (1998) Expression of amino-terminally truncated $\operatorname{PrP}$ in the mouse leading to ataxia and specific cerebellar lesions. Cell 93:203-214.

Tobler I, Gaus SE, Deboer T, Achermann P, Fischer M, Rülicke T, Moser M, Oesch B, McBride PA, Manson JC (1996) Altered circadian activity rhythms and sleep in mice devoid of prion protein. Nature 380:639-642.

Trotter J, Schachner M (1989) Cells positive for the O4 surface antigen isolated by cell sorting are able to differentiate into astrocytes or oligodendrocytes. Brain Res Dev Brain Res 46:115-122.

Vinson M, Rausch O, Maycox PR, Prinjha RK, Chapman D, Morrow R, Harper AJ, Dingwall C, Walsh FS, Burbidge SA, Riddell DR (2003) Lipid rafts mediate the interaction between myelin-associated glycoprotein (MAG) on myelin and MAG-receptors on neurons. Mol Cell Neurosci 22:344-352.

Waggoner DJ, Drisaldi B, Bartnikas TB, Casareno RL, Prohaska JR, Gitlin JD, Harris DA (2000) Brain copper content and cuproenzyme activity do not vary with prion protein expression level. J Biol Chem 275:7455-7458.

Weissmann C, Aguzzi A (1999) Perspectives: neurobiology. PrP’s double causes trouble. Science 286:914-915.

White AR, Enever P, Tayebi M, Mushens R, Linehan J, Brandner S, Anstee D, Collinge J, Hawke S (2003) Monoclonal antibodies inhibit prion replication and delay the development of prion disease. Nature 422:80-83.

Wilkins A, Majed H, Layfield R, Compston A, Chandran S (2003) Oligodendrocytes promote neuronal survival and axonal length by distinct intracellular mechanisms: a novel role for oligodendrocyte-derived glial cell line-derived neurotrophic factor. J Neurosci 23:4967-4974.

Zanata SM, Lopes MH, Mercadante AF, Hajj GN, Chiarini LB, Nomizo R, Freitas AR, Cabral AL, Lee KS, Juliano MA, De Oliveira E, Jachieri SG, Burlingame A, Huang L, Linden R, Brentani RR, Martins VR (2002) Stress-inducible protein 1 is a cell surface ligand for cellular prion that triggers neuroprotection. EMBO J 21:3307-3316. 